UNIVERSITY OF NOTTINGHAM

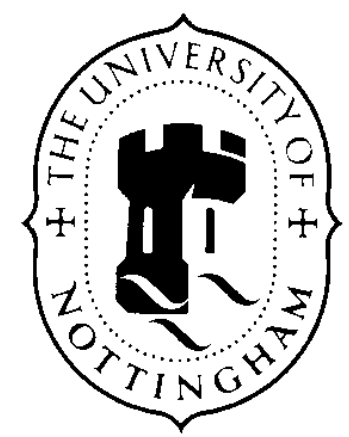

Discussion Papers in Economics

Discussion Paper

No. 08/09

What Makes Currencies Volatile?

An Empirical Investigation

By Michael Bleaney and Manuela Francisco

September 2008

2008

DP 08/09 


\title{
What Makes Currencies Volatile? An Empirical Investigation
}

\author{
Michael Bleaney \\ School of Economics, University of Nottingham \\ Manuela Francisco \\ World Bank, Washington DC, and University of Minho
}

\begin{abstract}
Real effective exchange rate volatility is examined for 90 countries using monthly data from January 1990 to June 2006. Volatility decreases with openness to international trade and per capita GDP, and increases with inflation, particularly under a horizontal peg or band, and with terms-of-trade volatility. The choice of exchange rate regime matters. After controlling for these effects, a free float adds at least $45 \%$ to the standard deviation of the real effective exchange rate, relative to a conventional peg, but most other regimes make little difference. The results are robust to alternative volatility measures and to sample selection bias.
\end{abstract}

Keywords: Exchange rate regimes, inflation, volatility.

JEL Nos: F31

\section{Acknowledgement}

The authors wish to thank Ishani Abeyratne for excellent research assistance. The views expressed here are those of the authors and should not be taken to represent those of the World Bank or of its Executive Board or of any of its member countries.

Corresponding author

Professor M. F. Bleaney, School of Economics, University of Nottingham, Nottingham NG7 2RD, U.K. Tel. (+44) 115951 5464; Fax (+44) 115951 4159. e-mail:

michael.bleaney@nottingham.ac.uk 


\section{Introduction}

What makes currencies volatile? The empirical analysis of real exchange rate volatility is a relatively neglected area, even though the topic has long been a concern for academics and policy-makers. ${ }^{1}$ Although volatility is known to be higher in economies with a low ratio of international trade to GDP and with lower per capita income (e.g. Bravo-Ortega and di Giovanni, 2006), we lack systematic studies of a large number of countries, or quantitative estimates of how much volatility can be reduced by various forms of intervention.

One strand of investigation in previous research has compared volatility in the advanced countries under the Bretton Woods system and subsequently. The clear conclusion is that real exchange rate volatility has increased, even though other dimensions of macroeconomic volatility have not (Baxter and Stockman, 1989; Flood and Rose, 1995; Mussa, 1986; Rose, 1996), a phenomenon identified by Obstfeld and Rogoff (2000) as one of the six major puzzles of macroeconomics. Using a century of data for real exchange rate volatility against the US dollar for the UK, Canada, Japan and France, Hasan and Wallace (1996) also find significantly greater volatility under floating rates.

These findings suggest that the exchange rate regime matters. It may, however, matter less than this implies if many of a country's trading partners are floating against one

\footnotetext{
${ }^{1}$ Academics have debated whether real exchange rate volatility adversely affects trade and growth (e.g. Aghion et al., 2006; Clark et al., 2004). Policy-makers seem very reluctant to allow exchange rates to fluctuate freely (under $15 \%$ of countries currently do so according to the IMF), and frequently complain about them when they do allow them to do so.
} 
another, as is currently the case. In these circumstances, a single-currency peg may not achieve much greater stability than a float, and a basket peg that better reflects the pattern of countries' trade may achieve greater real effective exchange rate stability than a singlecurrency peg. It is also very much of an open question how much volatility can be reduced by managing a float. This is the type of issue that we investigate.

There are some studies of exchange rate volatility in cross-country samples. Devereux and Lane (2003) examine monthly nominal bilateral exchange rate volatility in a large sample of country pairs over the period 1995 to 2000, and find volatility to be negatively related to trade flows, business cycle asymmetry, financial development and external debt, and positively related to the product of the countries’ GDP. Hau (2002) reports real effective exchange rate volatility to be negatively related to the ratio of trade to GDP. Bravo-Ortega and di Giovanni (2006) find volatility to be negatively related to trade openness and per capita GDP, and positively related to trade taxes and an index of remoteness (trade-weighted distance from the rest of the world). They conclude that trade costs (transport costs plus taxes) raise volatility. Hausmann et al. (2006) focus on the much higher real effective exchange rate volatility of developing countries in annual data over the period 1980-2000. They find that the difference cannot be explained by the greater variance of terms-of-trade shocks.

One variable that has not featured in these studies is inflation. We show that, even at low to medium levels, inflation is quite important for real effective exchange rate volatility, 
especially under some form of peg or band. Exchange rate regime influences have also been rather neglected. ${ }^{2}$

A distinctive feature of the present study is that we seek to identify the influence of the exchange rate regime in some detail. We use the IMF's current de facto methodology for identifying regimes. We then measure real effective exchange rate volatility over periods when there are no regime switches. This inevitably means that the episodes over which volatility is measured are of unequal length, but we show by experimenting with alternative minimum lengths that this makes little difference to the results. We also test the robustness of the results by using several different measures of volatility and by varying the threshold above which high-inflation observations are excluded. We use a sample of 90 countries over the period 1990-2006. ${ }^{3}$ We show that regime effects are important and provide a quantitative estimate of them.

The remainder of the paper is organized as follows. After an informal theoretical discussion in Section 2, the different volatility measures are presented in Section 3. Section 4 discusses the classification system for exchange rate regimes. After some preliminary data analysis in Section 5, the main empirical results are presented in Section 6. Section 7 concludes.

\footnotetext{
${ }^{2}$ Hau (2002) and Rose (1996) are two studies that do allow for regime effects.
} 


\section{Theoretical Considerations}

The micro-founded models currently popular in international macroeconomics assume monopolistically competitive firms and incorporate downward-sloping demand functions for a country's goods in international markets (e.g. Bergin, 2006). It is a natural step from there to the concept of an equilibrium real exchange rate, to which the actual rate tends to revert. At the equilibrium, net trade will be at a value that, after adding net property income flows, will be consistent with a medium-run equilibrium in the current account balance. This is not a full stock equilibrium, because the country will normally be accumulating or losing net external assets, which will impart some trend to net property income flows and therefore to the equilibrium level of net trade and the real exchange rate. The medium-run equilibrium in the current account balance will reflect the savings and investment propensities of the country, which in turn will be influenced by its level of development, demographics, the fiscal balance and institutional and other characteristics (see Williamson and Mahar, 1998, for a fuller discussion). More formally, let (the logarithm of) the real exchange rate (REER) consist of an equilibrium (EQU) and a disequilibrium component (DIS):

$$
R E E R=E Q U+D I S
$$

The relationship between the current account balance $(C A)$ and the real exchange rate is a function of factors such as net foreign assets (NFA), the terms of trade (TOT), the level of aggregate demand in the economy $(Y)$ and trade policy $(P O L)$ :

\footnotetext{
${ }^{3}$ Data for regime classifications using the IMF’s current methodology are not available before 1990.
} 


$$
C A=\mathrm{f}(R E E R, N F A, T O T, Y, P O L)
$$

This equation can be inverted, for $C A$ set at its trend level, $\overline{C A}$, to solve for the equilibrium real exchange rate:

$$
E Q U=f^{-1}(\overline{C A}, N F A, T O T, Y, P O L)
$$

Barisone et al. (2006) provide evidence from six major countries that the actual rate reverts towards an equilibrium that is estimated using this approach. The variance of the real effective exchange rate is given by:

$$
\operatorname{var}(R E E R)=\operatorname{var}(E Q U)+\operatorname{var}(D I S)+2 \operatorname{cov}(E Q U, D I S)
$$

The variance of the equilibrium component will reflect the variance of the factors shown in equation (3), of which we now provide an informal discussion. For example a country that is poor in capital might undertake major reforms to address institutional problems that were previously inhibiting capital inflows, thus appreciating its equilibrium real exchange rate. The covariance term captures how disequilibrium movements in the real exchange rate might affect the equilibrium itself. For example, a real exchange rate appreciation reduces the domestic currency price of imports; with quantitative controls on imports, this raises the tariff equivalent of the quantitative controls, thus effectively 
tightening trade policy and pulling the equilibrium real exchange rate towards the actual one, implying a positive covariance. With net foreign assets the effect can work in either direction, depending on the relative size and on the currency composition of assets and liabilities. ${ }^{4}$

The variance of the disequilibrium component is likely to reflect different factors. BravoOrtega and di Giovanni (2006) show theoretically that country-specific productivity shocks have larger real exchange rate effects in more closed economies because of greater geographical and artificial obstacles to trade adjustment. The intuition is that country-specific shocks change the relative price of non-tradeables across countries more than the relative price of tradeables. Hau (2002) suggests that less open economies have more volatile real exchange rates because nominal exchange rate shocks have smaller import price effects. When currencies are viewed as assets, their volatility under floating is likely to be determined by the range over which there is no clear evidence of misalignment. Bleaney (2008) shows that this implies greater volatility if the ratio of international trade to GDP is smaller, because of the tendency to use GDP as the denominator in defining long-run current account sustainability. ${ }^{5}$

The exchange rate regime is potentially an important determinant of the disequilibrium component of volatility. In a target zone, for example, the authorities’ intervention policy

\footnotetext{
${ }^{4}$ In richer countries, where liabilities tend to be denominated in domestic currency, an appreciation tends to worsen the net asset position, whereas in poorer countries, with liabilities denominated in foreign currency and liabilities exceeding assets, it tends to improve it (Lane and Shambaugh, 2007). The covariance would thus tend to be negative for richer countries and positive for poorer ones.
} 
may co-ordinate mean-reverting speculative activity that might otherwise be outweighed by momentum traders (Reitz and Taylor, 2008). An important caveat is that this is only likely to be true if the equilibrium rate is within, or not far outside, the target zone. If the authorities are trying to maintain an exchange rate that is significantly away from its equilibrium value, an exercise which is futile in the long run, their interventions in the foreign exchange market may actually increase volatility. For example, policy-makers may attach some value to nominal exchange rate stability (and to stability against some particular currency rather than against a trade-weighted average), and allow some real appreciation in the presence of inflation. This ultimately has to be corrected, and implies that real exchange rate volatility under some forms of exchange rate management may increase with the inflation rate. Frankel (2005) shows that finance ministers are more likely to lose their jobs after a devaluation. This provides a rationale for the assumption, frequently made in currency crisis models, that there is a fixed cost of adjusting a peg. If true, this imparts a significant element of nominal rigidity to a pegged rate system. More generally, inflation creates a tension between nominal and real exchange rate stability. Certainly high-inflation episodes are characterised by exceptionally high real exchange rate volatility (Bleaney, 1996, Table 1; Gonzaga and Terra, 1997), although these could perhaps be dismissed as exceptional cases. Thus the effect of exchange rate intervention on the disequilibrium component of real exchange rate volatility can operate in both directions.

\footnotetext{
${ }^{5}$ This argument assumes that the elasticity of trade flows with respect to real exchange rate movements is similar across countries, so that a given real exchange rate movement has a larger impact on the trade balance as a proportion of GDP in more open economies.
} 
By including exchange rate regime dummies along with structural and other variables in our volatility regression, we attempt to control for the disequilibrium as well the equilibrium components of volatility.

\section{Measurement of Volatility}

We consider four different ways to measure volatility, all based on the log of the real effective exchange rate index as given in International Financial Statistics. The four measures are (1) the mean absolute monthly change (MAC); (2) the standard deviation of monthly changes (SDC); (3) the root mean square monthly change (RMSC); and the standard deviation of the level (SDL), all multiplied by 100 so that the numbers approximate to percentages. Formally, if $x_{\mathrm{t}}$ is the log real effective exchange rate index in month $t, \Delta$ is the first-difference operator, and a bar above a variable indicates a mean, then

$$
\begin{aligned}
& M A C=\frac{100}{n-1} \sum_{t=2}^{n}\left|\Delta x_{t}\right| \\
& S D C=\left(\frac{100}{n-1} \sum_{t=2}^{n}\left(\Delta x_{t}-\overline{\Delta x}\right)^{2}\right)^{1 / 2} \\
& R M S C=\left(\frac{100}{n-1} \sum_{t=2}^{n}\left(\Delta x_{t}\right)^{2}\right)^{1 / 2} \\
& S D L=\left(\frac{100}{n-1} \sum_{t=1}^{n}\left(x_{t}-\bar{x}\right)^{2}\right)^{1 / 2}
\end{aligned}
$$

Of these, MAC yields the lowest numbers, because it attaches less weight to big changes than $S D C$, while $R M S C$ is in effect a standard deviation about zero rather than about the 
mean change, and therefore takes account of drift. It differs from SDC only by the square of the mean change, which is small in many cases. Finally, $S D L$ is the standard deviation of the level about the estimated sample mean, and will reflect the cumulative effect of monthly changes, including their persistence and any tendency to mean-reversion, as well as their absolute size. It is difficult to say a priori which is the best measure, because it depends on the time horizon and on the similarity of the time series properties of the series. Certainly firms investing in trading relationships or productive assets are likely to be more worried about how far the real exchange rate might move over a longer period, such as several years, rather than one month. Although this argument suggests $S D L$ as the best measure, this might not be true under certain stringent conditions. If the real effective exchange rate series of different countries have very similar time series properties, then a measure based on changes should be less noisy because it is less dependent on particular shock realisations (since the stochastic element is cumulated in a levels measure). ${ }^{6}$ This is a strong assumption to make, however, particularly since the exchange rate regime is likely to affect the time series properties of the real exchange rate. Rather than take a position on this issue, we present results with several alternative volatility measures.

\footnotetext{
${ }^{6}$ In previous work $S D C$ and $S D L$ have been the most commonly used measures. Suppose that in each country (i), the relevant equation is: $\Delta \mathrm{x}_{\mathrm{t}}=a_{\mathrm{i}}+b_{\mathrm{i}} \Delta \mathrm{x}_{\mathrm{t}-1}-c_{\mathrm{i}} \mathrm{x}_{\mathrm{t}-1}+u_{\mathrm{it}}$, where $u$ is a random error, and $a_{\mathrm{i}}, b_{\mathrm{i}}$ and $c_{\mathrm{i}}$ are parameters that are fixed for each country. If $a, b$ and $c$ are identical across countries, but the variance of $u_{\mathrm{i}}$ is not, in the long run the variance of $x$ should be proportional to the variance of $u_{\mathrm{i}}$, and the variance of $u_{\mathrm{i}}$ is best estimated from changes in $x$. If the parameters vary across countries, the ratio of variances of $x$ in different
} 


\section{Exchange Rate Regime Classifications}

The IMF has always published information about the exchange rate regimes of its member countries. Unfortunately, until 1997, this was simply based on the countries' own classification of their regime, which was sometimes inaccurate. Because of this, since 1999, the IMF has published its own classification of a country's regime, as described in Table 1. Bubula and Ötker-Robe (2002) provide a revised classification for earlier years back to 1990 on the same principles. This is the data set that we use. ${ }^{7}$ Alternative historical classifications, based on different statistical methodologies, have been provided by Levy-Yeyati and Sturzenegger (2005), Reinhart and Rogoff (2004) and Shambaugh (2004). Unfortunately, these disagree with each other as much as with countries' own reported classifications (Bleaney and Francisco, 2007). Two of them are in any case unsuitable for our present purposes since they only generate one classification for each calendar year. More generally, statistical procedures have limitations, and it would be difficult to claim that they are superior to the IMF's current methodology (the motivation for developing these alternative measures was the weaknesses in the old IMF procedure rather than in the new one). Indeed, since the volatility of the nominal exchange rate is an important ingredient of all statistically-based classification schemes, a statistical approach carries a significant risk of endogeneity bias with respect to real exchange rate volatility. This risk should be smaller, although probably not entirely absent, with a judgemental approach such as that currently used by the IMF. We

countries will also reflect different values of $a, b$ and $c$, which will only be captured in $S D L$. We show below that we get similar results whatever measure we use.

${ }^{7}$ We are grateful to Harald Anderson of the IMF for providing the data. 
therefore confine our analysis to the period covered by the IMF's current procedures, as backdated by Bubula and Ötker-Robe (2002).

Table 1. Regime Classifications

\begin{tabular}{|c|c|}
\hline 1 & No separate legal tender \\
\hline 2 & Currency board arrangements \\
\hline 3 & Conventional fixed pegs \\
\hline 4 & Horizontal bands \\
\hline 5 & Crawling pegs \\
\hline 6 & Crawling bands \\
\hline 7 & Managed float \\
\hline 8 & Independent float \\
\hline
\end{tabular}

Notes. No separate legal tender includes currency unions as well as the use of a foreign currency as legal tender. Categories 3 and 5 are defined by a maximum fluctuation of $\pm 1 \%$ around the central parity; a wider range is classified in category 4 or 6 , as appropriate. In categories 5 and 6 the central parity is adjusted relatively frequently by small amounts. Category 7 covers cases where the monetary authority attempts to influence the exchange rate without any specified path or target. In category 8 the exchange rate is marketdetermined.

There is a choice to be made between measuring real exchange rate volatility in periods of fixed length, across all countries, even though there may have been a switch of exchange rate regime during the period, and measuring it over periods characterised by the same exchange rate regime, which will necessarily be of unequal length. We choose the latter option. To deal with the problem of varying episode length, in the empirical analysis we exclude episodes where the regime lasted for too short a time (less than four quarters), and we also split exceptionally long periods of the same regime into two or three shorter episodes. This helps to prevent countries with few regime switches from being too severely underrepresented. Any period of 48 quarters is split into three episodes of equal or nearly equal length, and any period of between 32 and 47 quarters is 
split into two episodes of equal or nearly equal length. Each episode thus defined represents an observation in the empirical analysis that follows. Thus, for the United States, which has been freely floating throughout, there are three 22-quarter episodes, lasting respectively from January 1990 to June 1995, July 1995 to December 2000, and January 2001 to June 2006, with real exchange rate volatility measured separately over each of these three episodes, each of which represents an observation in the regressions that follow. For some other countries, there are more than three episodes of shorter average length. By increasing the cut-off point for the minimum length of an episode to be included in the analysis, we can check that the inclusion of more episodes from some countries than others is not affecting the results.

\section{Preliminary Data Analysis}

In order to avoid the influence of outliers, all episodes where the mean monthly change in the logarithm of the consumer price index is greater than 0.03 (equivalent to an annual inflation rate of $43.33 \%$ ) are excluded, as are those containing fewer than four quarters. This reduces the observations from 330 to 274 . Table 2 provides some basic statistical data for this sample. The mean absolute monthly change in the real exchange rate is only about two-thirds of the mean standard deviation of monthly changes, which is only just less than the mean root mean square monthly change, but the standard deviation of the level is about three times as large as these last two. The coefficient of variation is about one for most measures, but more like 0.7 for the mean absolute monthly change. Because volatilities cannot be negative, there is a significant positive skew, as indicated by the 
relative distances from the mean of the maximum and minimum. The average episode is 18.4 quarters in length, with a standard deviation of 5.9.

Table 2. Some Basic Statistics

\begin{tabular}{|c|c|c|c|c|}
\hline Variable & Mean & $\begin{array}{c}\text { St. } \\
\text { Deviation }\end{array}$ & Minimum & Maximum \\
\hline \multicolumn{4}{|c|}{ Real exchange rate volatility measures } \\
\hline $\begin{array}{c}\text { Mean absolute change } \\
\text { (MAC) }\end{array}$ & 1.43 & 1.06 & 0.37 & 7.86 \\
\hline St. dev. of change (SDC) & 2.16 & 2.31 & 0.49 & 22.31 \\
\hline $\begin{array}{c}\text { Root mean sq. change } \\
\text { (RMSC) }\end{array}$ & 2.22 & 2.34 & 0.50 & 22.43 \\
\hline St. dev. of level (SDL) & 6.45 & 5.60 & 0.98 & 43.27 \\
\hline $\begin{array}{c}\text { Other variables } \\
\text { Length of episode } \\
\text { (quarters) }\end{array}$ & 18.41 & 5.89 & 4 & 30 \\
\hline $\begin{array}{c}\text { ln per capita GDP (2000 } \\
\text { \$US) }\end{array}$ & 8.19 & 1.60 & 4.45 & 10.52 \\
\hline Openness (trade/GDP) & 0.618 & 0.225 & 0.187 & 1.332 \\
\hline Monthly CPI inflation & 0.61 & 0.60 & -0.03 & 2.76 \\
\hline Terms-of-trade volatility & 8.41 & 8.96 & 0.04 & 51.0 \\
\hline
\end{tabular}

Notes. These statistics refer to the 274 episodes of minimum length four quarters for which real effective exchange rate data exist, and with mean inflation below 0.03 . Inflation is the month-to-month change in the logarithm of the consumer price index multiplied by 100 . Terms-of-trade volatility is the standard deviation of the logarithm over five years centred on the mid-point of the episode, multiplied by 100 . Terms of trade are calculated as (exports at current prices)/(exports at constant prices) divided by (imports at current prices)/(imports at current prices), or where this is not available as export unit values divided by import unit values, as given in World Development Indicators.

The correlations between the different volatility measures are given in Table 3. All the correlations are above 0.75 , with that between the mean absolute change and the standard deviation of the level being the lowest. The correlation between the standard deviation of the change and the root mean square change is very close to one, which indicates that drift is not a major factor. 
$\underline{\text { Table 3. Correlations Between Alternative Volatility Measures }}$

\begin{tabular}{|c|c|c|c|}
\hline & MAC & SDC & RMSC \\
\hline MAC & 1 & & \\
\hline SDC & 0.886 & 1 & 1 \\
\hline RMSC & 0.896 & 0.998 & 0.813 \\
\hline SDL & 0.777 & 0.805 & \\
\hline
\end{tabular}

Notes. These statistics refer to the 274 episodes of minimum length four quarters with mean inflation below 0.03. For definitions see equation (1).

Table 4 shows some basic statistics by regime. The two smallest categories (currency boards (2) and crawling bands (6)) have been amalgamated with a neighbouring category (no separate legal tender (1) and crawling pegs (5) respectively), but otherwise no regime represents more than $21 \%$ of the observations. Real exchange rate volatility tends to be highest under floats (with little difference between managed and independent floats), and lowest under some intermediate regimes (pegs with wide bands (4) and crawls (5 and 6)). Alternative volatility measures (not shown in the table) display a similar pattern. Inflation is distinctly higher in crawls and managed floats, and these regimes are more common in poorer countries. There is a slight tendency for openness to decline with regime flexibility, since larger countries tend to have more flexible regimes (Bleaney and Francisco, 2008). Somewhat surprisingly, the least flexible regimes tend to be associated with higher terms-of-trade volatility. 
Table 4. Basic Statistics by Exchange Rate Regime

\begin{tabular}{|c|c|c|l|c|c|c|}
\hline Regime & Episodes & $\begin{array}{c}\text { St. dev. } \\
\text { of REER } \\
\text { level }\end{array}$ & $\begin{array}{l}\text { Monthly } \\
\text { inflation }\end{array}$ & $\begin{array}{c}\text { ln } \\
\text { (GDP } \\
\text { p.c.) }\end{array}$ & $\begin{array}{c}\text { Open- } \\
\text { ness }\end{array}$ & $\begin{array}{c}\text { TOT } \\
\text { volat- } \\
\text { ility }\end{array}$ \\
\hline $1 / 2$ & 45 & 6.78 & 0.315 & 8.02 & 0.675 & 11.90 \\
\hline 3 & 54 & 6.17 & 0.381 & 8.13 & 0.710 & 11.89 \\
\hline 4 & 32 & 3.43 & 0.381 & 9.64 & 0.649 & 9.55 \\
\hline $5 / 6$ & 38 & 4.91 & 0.992 & 7.86 & 0.537 & 6.63 \\
\hline 7 & 55 & 7.76 & 0.917 & 7.40 & 0.625 & 8.79 \\
\hline 8 & 50 & 8.10 & 0.462 & 8.59 & 0.501 & 6.35 \\
\hline & & & & & & \\
\hline All & 274 & 6.45 & 0.608 & 8.19 & 0.618 & 8.41 \\
\hline
\end{tabular}

Notes. These statistics refer to episodes of minimum length four quarters with mean inflation below 0.03 . For definitions of regimes see Table 1. For definitions of variables see Table 2.

\section{Empirical Results}

In this section we develop an empirical model of real effective exchange rate volatility.

First we consider per capita GDP, trade openness, terms-of-trade volatility and inflation.

We also control for episode length, which is significant for one volatility measure. Then we introduce dummies for different exchange rate regimes (treating a conventional peg as the omitted category), and finally we allow for the inflation effect to vary with the exchange rate regime. Thus the model is:

$$
R V O L_{i t}=a+b I N F_{i t}+c X_{i t}+d E R R_{i t}+e\left(E R R_{i t} * I N F_{i t}\right)+u_{i t}
$$


where $R V O L_{i t}$ is the volatility of the real effective exchange rate in episode $t$ in country $i$; $I N F$ is the inflation rate; $X$ is a vector of other exogenous variables (e.g. openness); ERR is a vector of exchange rate regime dummies; and $u$ is a stochastic term.

Table 5 shows the results for the basic model without regime effects or interaction terms. Unless otherwise stated, all the regressions presented omit episodes shorter than four quarters in length and with monthly inflation greater than three percentage points. The model explains $30 \%$ to $40 \%$ of observed volatility. Volatility increases significantly with the length of the episode for the $S D L$ measure only, which is not surprising because MAC and RMSC are calculated using changes rather than levels. Volatility decreases with per capita GDP and openness, and increases with inflation and terms-of-trade volatility. In terms of the effect of an increase of one standard deviation (i.e. multiplying the coefficients in Table 5 by the standard deviations in Table 2), inflation is the most important factor. The second most important factor is terms-of-trade volatility. Openness lags some way behind: for all volatility measures, a one-S.D. change has only about a third of the effect of a one-S.D. change in the inflation rate. As the last row of Table 5 indicates, four other geographical variables (land area, population density, GDPweighted distance from other countries and a dummy for landlockedness) were collectively (and also individually) insignificant except in the case of $S D L$, and were omitted from the model. All of these variables tend to be correlated with openness, so this implies that openness is a sufficient variable to capture the effects of geography. ${ }^{8}$ 
Table 5. An Initial Regression for Real Effective Exchange Rate Volatility

\begin{tabular}{|c|c|c|c|}
\hline & \multicolumn{3}{|c|}{ Volatility Measure } \\
\hline & MAC & RMSC & SDL \\
\hline Independent variables & & & $5.09^{* *}$ \\
& $1.26^{* *}$ & $1.77^{* *}$ & $(5.84)$ \\
\hline Constant & $(6.79)$ & $(4.76)$ & $0.219^{* *}$ \\
& -0.0040 & 0.0281 & $(4.38)$ \\
\hline Episode length & $(-0.38)$ & $(1.30)$ & $-0.446^{*}$ \\
(quarters) & $-0.106^{*}$ & $-0.251^{*}$ & $(-2.16)$ \\
\hline In (per capita GDP) & $(-2.38)$ & $(-2.49)$ & $-3.70^{* *}$ \\
& $-0.659^{* *}$ & $-1.19^{*}$ & $(-3.31)$ \\
\hline Openness & $(-3.08)$ & $(-2.30)$ & $0.140^{* *}$ \\
& $0.0264^{* *}$ & $0.0579^{* *}$ & $(3.70)$ \\
\hline TOT volatility & $(3.55)$ & $(3.55)$ & $\left(5.70^{* *}\right.$ \\
& $0.723^{* *}$ & $1.32^{* *}$ & $(4.52)$ \\
\hline Monthly inflation rate & $(4.97)$ & & 274 \\
\hline Observations & 274 & 274 & 0.341 \\
\hline R-squared & 0.416 & 0.317 & 4.59 \\
\hline Standard error & 0.821 & 1.96 & $3.00^{*}(p=0.019)$ \\
\hline F-statistic (4, 264) & $0.98(p=0.419)$ & $1.76(p=0.137)$ & $(p)$ \\
\hline
\end{tabular}

Notes. Figures in parentheses are heteroscedasticity-robust $t$-statistics. ${ }^{*}(* *)$ denotes significantly different from zero at the 0.05 (0.01) level. For definition of volatility measures see equation (1). Sample excludes all episodes shorter than four quarters and with monthly inflation $>0.03$. The F-statistic refers to a joint test of zero coefficients on four omitted geographical variables: land area, population density, GDPweighted average distance from other countries (all in logs), and a dummy for landlockedness.

There is a possible concern that these results are unduly influenced by the inequality in episode lengths (and the consequent overrepresentation of countries with more regime changes), or by the particular choice of threshold for excluding high-inflation episodes. Accordingly Table 6 shows regressions similar to that in Table 5 for the $S D L$ measure except with different inflation thresholds, but keeping the minimum episode length at

\footnotetext{
${ }^{8}$ In the $S D L$ regression, land area is significant, and when it is included, openness becomes insignificant. For simplicity, however, we keep the same specification for $S D L$ as for the other two volatility measures.
} 
four quarters, and Table 7 shows regressions with longer minimum episode lengths. In neither case do the results vary much from those in Table 5 (the same is also true for other volatility measures, although the results are not shown).

Table 6. Samples with Different Upper Limits for Inflation

\begin{tabular}{|c|c|c|c|c|}
\hline & \multicolumn{4}{|c|}{ Volatility Measure } \\
\hline & SDL & SDL & SDL & SDL \\
\hline $\begin{array}{c}\text { Including obs. with } \\
\text { mean monthly } \\
\text { inflation up to: }\end{array}$ & 2.00 & 3.00 & 4.00 & 5.00 \\
\hline Independent variables & & & & \\
\hline Constant & $4.84^{* *}$ & $5.09^{* *}$ & $5.39^{* *}$ & $5.88^{* *}$ \\
& $(5.74)$ & $(5.84)$ & $(6.01)$ & $(6.11)$ \\
\hline Episode length & $0.250^{* *}$ & $0.219^{* *}$ & $0.210^{* *}$ & $0.194^{* *}$ \\
(quarters) & $(5.14)$ & $(4.38)$ & $(4.11)$ & $(3.84)$ \\
\hline ln (per capita GDP) & -0.349 & $-0.446^{*}$ & $-0.504^{*}$ & $-0.630^{* *}$ \\
& $(-1.65)$ & $(-2.16)$ & $(-2.48)$ & $(-3.22)$ \\
\hline Openness & $-4.11^{* *}$ & $-3.70^{* *}$ & $-3.70^{* *}$ & $-3.78^{* *}$ \\
& $(-3.63)$ & $(-3.31)$ & $(-3.29)$ & $(-3.27)$ \\
\hline TOT volatility & $0.127^{* *}$ & $0.140^{* *}$ & $0.135^{* *}$ & $0.138^{* *}$ \\
& $(3.44)$ & $(3.70)$ & $(3.56)$ & $(3.76)$ \\
\hline Monthly inflation rate & $4.77^{* *}$ & $3.70^{* *}$ & $3.33^{* *}$ & $2.71^{* *}$ \\
& $(5.14)$ & $(5.38)$ & $(5.32)$ & $(5.82)$ \\
\hline & & & & \\
\hline Observations & 261 & 274 & 278 & 285 \\
\hline R-squared & 0.359 & 0.341 & 0.342 & 0.362 \\
\hline Standard error & 4.45 & 4.59 & 4.67 & 4.78 \\
\hline
\end{tabular}

Notes. Figures in parentheses are heteroscedasticity-robust $t$-statistics. ${ }^{*}(* *)$ denotes significantly different from zero at the 0.05 (0.01) level. For definition of volatility measures see equation (1). Minimum episode length four quarters. The regression from Table 5 is italicized. 
Table 7. Samples with Different Minimum Episode Lengths

\begin{tabular}{|c|c|c|c|c|}
\hline & \multicolumn{4}{|c|}{ Volatility Measure } \\
\hline & SDL & SDL & SDL & SDL \\
\hline $\begin{array}{c}\text { Minimum episode } \\
\text { length (quarters) }\end{array}$ & 4 & 8 & 12 & 16 \\
\hline Independent variables & & & & \\
\hline Constant & $5.09^{* *}$ & $5.36^{* *}$ & $5.31^{* *}$ & $4.72^{* *}$ \\
& $(5.84)$ & $(5.80)$ & $(5.21)$ & $(5.05)$ \\
\hline Episode length & $0.219^{* *}$ & $0.234^{* *}$ & $0.239^{* *}$ & $0.273^{* *}$ \\
(quarters) & $(4.38)$ & $(3.85)$ & $(2.66)$ & $(3.91)$ \\
\hline In (per capita GDP) & $-0.446^{*}$ & $-0.493^{*}$ & $-0.472^{*}$ & -0.410 \\
& $(-2.16)$ & $(-2.26)$ & $(-2.04)$ & $(-1.96)$ \\
\hline Openness & $-3.70^{* *}$ & $-4.18^{* *}$ & $-4.23^{* *}$ & $-3.89^{* *}$ \\
& $(-3.31)$ & $(-3.57)$ & $(-3.44)$ & $(-3.67)$ \\
\hline TOT volatility & $0.140^{* *}$ & $0.141^{* *}$ & $0.142^{* *}$ & $0.150^{* *}$ \\
& $(3.70)$ & $(3.63)$ & $(3.56)$ & $(4.07)$ \\
\hline Monthly inflation rate & $3.70^{* *}$ & $3.67^{* *}$ & $3.73^{* *}$ & $3.88^{* *}$ \\
& $(5.38)$ & $(4.93)$ & $(4.56)$ & $(4.73)$ \\
\hline & & & & \\
\hline Observations & 274 & 252 & 234 & 215 \\
\hline R-squared & 0.341 & 0.364 & 0.346 & 0.400 \\
\hline Standard error & 4.59 & 4.50 & 4.62 & 4.09 \\
\hline
\end{tabular}

Notes. Figures in parentheses are heteroscedasticity-robust $t$-statistics. ${ }^{*}\left({ }^{* *}\right)$ denotes significantly different from zero at the 0.05 (0.01) level. For definition of volatility measures see equation (1). Sample excludes all episodes with mean monthly inflation greater than 0.03 . The regression from Table 5 is italicized.

\subsection{Regime Effects}

We turn now to exchange rate regime effects. Does the inclusion of regime dummies improve on the model shown in Table 5? As well as including a dummy for each regime (as aggregated in Table 4, and using a conventional peg to a single currency as the omitted category), we also allow pegs to a basket of currencies to be different from pegs to a single currency, since they may help to stabilise the real effective exchange rate. 
Table 8 shows the OLS results. Although altogether six regime dummies were added to the regression, those for four of them (those for a hard peg, a basket peg, a conventional band and a managed float) are consistently insignificant. Crawling pegs and bands have a significant negative coefficient and independent floats a significantly positive one. Thus crawling pegs and bands seem to reduce volatility at a given inflation rate, while an independent float increases it, relative to a conventional peg. On the other hand, a managed float does not, despite the high average volatility under managed floats shown in Table 4. This is because the model is already explaining this feature by inflation, which is relatively high under managed floats.

There is a concern that these results are unduly sensitive to outliers. To address this, we have re-estimated the equation using robust regression techniques (Table 9). Table 9 shows that these concerns are justified, both because of the substantial number of outliers identified (as indicated at the foot of Table 9) and because they are all in the upper tail, reflecting the positive skewness in the data. Moreover the results for exchange rate regimes are somewhat different in Table 9, compared with Table 8. The crawl dummy is still negative but only significant in one out of three cases. Hard pegs also have a negative coefficient that is significant in one case. Managed floats now have a positive coefficient that is significant at the 0.01 level in two cases. The most noticeable feature is that independent floats now have a highly significant positive coefficient. 
Table 8. Adding Exchange Rate Regime Dummies

\begin{tabular}{|c|c|c|c|}
\hline & \multicolumn{3}{|c|}{ Volatility Measure } \\
\hline & MAC & RMSC & SDL \\
\hline \multicolumn{4}{|l|}{ Independent variables } \\
\hline Constant & $\begin{array}{l}0.90 * * \\
(3.20)\end{array}$ & $\begin{array}{l}1.19 * \\
(2.31)\end{array}$ & $\begin{array}{r}4.62^{* *} \\
(3.40) \\
\end{array}$ \\
\hline $\begin{array}{l}\text { Episode length } \\
\text { (quarters) }\end{array}$ & $\begin{array}{l}-0.0075 \\
(-0.63)\end{array}$ & $\begin{array}{l}0.017 \\
(0.67)\end{array}$ & $\begin{array}{l}2.07^{* *} \\
(3.40)\end{array}$ \\
\hline $\ln$ (per capita GDP) & $\begin{array}{l}-0.114^{*} \\
(-2.22) \\
\end{array}$ & $\begin{array}{l}-0.270^{*} \\
(-2.03) \\
\end{array}$ & $\begin{array}{r}-0.502^{*} \\
(-2.04) \\
\end{array}$ \\
\hline Openness & $\begin{array}{l}-0.357 \\
(-1.50)\end{array}$ & $\begin{array}{l}-0.810 \\
(-1.39)\end{array}$ & $\begin{array}{l}-3.07^{*} \\
(-2.27)\end{array}$ \\
\hline TOT volatility & $\begin{array}{c}0.0273^{* *} \\
(3.48) \\
\end{array}$ & $\begin{array}{c}0.0574^{* *} \\
(3.30) \\
\end{array}$ & $\begin{array}{c}0.133^{* *} \\
(3.52) \\
\end{array}$ \\
\hline Monthly inflation rate & $\begin{array}{c}0.836^{* *} \\
(5.61)\end{array}$ & $\begin{array}{l}1.56^{* *} \\
(4.88)\end{array}$ & $\begin{array}{r}4.27 * * \\
(5.93)\end{array}$ \\
\hline \multicolumn{4}{|l|}{ Regime dummies } \\
\hline Hard peg (1 or 2$)$ & $\begin{array}{l}0.032 \\
(0.19) \\
\end{array}$ & $\begin{array}{l}0.318 \\
(0.82) \\
\end{array}$ & $\begin{array}{l}-0.058 \\
(-0.06) \\
\end{array}$ \\
\hline $\begin{array}{c}\text { Basket peg } \\
\text { (subset of 3) }\end{array}$ & $\begin{array}{l}-0.009 \\
(-0.03) \\
\end{array}$ & $\begin{array}{l}0.365 \\
(0.36) \\
\end{array}$ & $\begin{array}{l}-0.740 \\
(-0.30) \\
\end{array}$ \\
\hline Conventional band (4) & $\begin{array}{l}0.015 \\
(0.09) \\
\end{array}$ & $\begin{array}{l}0.0337 \\
(1.07) \\
\end{array}$ & $\begin{array}{l}-0.107 \\
(-0.11)\end{array}$ \\
\hline Crawl (5 or 6) & $\begin{array}{c}-0.504 * * \\
(-2.64)\end{array}$ & $\begin{array}{c}-0.985^{* *} \\
(-2.78)\end{array}$ & $\begin{array}{l}-3.08^{* *} \\
(-2.88)\end{array}$ \\
\hline Managed float (7) & $\begin{array}{l}0.133 \\
(0.74)\end{array}$ & $\begin{array}{l}0.137 \\
(0.38)\end{array}$ & $\begin{array}{l}-0.154 \\
(-0.16)\end{array}$ \\
\hline Independent float (8) & $\begin{array}{c}0.824^{* *} \\
(3.95) \\
\end{array}$ & $\begin{array}{l}1.28 * * \\
(2.98)\end{array}$ & $\begin{array}{l}2.08^{*} \\
(2.04)\end{array}$ \\
\hline Observations & 274 & 274 & 274 \\
\hline R-squared & 0.540 & 0.387 & 0.403 \\
\hline Standard error & 0.737 & 1.87 & 4.42 \\
\hline
\end{tabular}

Notes. Figures in parentheses are heteroscedasticity-robust $t$-statistics. ${ }^{*}(* *)$ denotes significantly different from zero at the 0.05 (0.01) level. For definition of volatility measures see equation (1). Sample excludes all episodes shorter than four quarters and with monthly inflation $>0.03$. The omitted regime category is a conventional single-currency peg. 
Table 9. Adding Exchange Rate Regime Dummies (Downweighting Outliers)

\begin{tabular}{|c|c|c|c|}
\hline & \multicolumn{3}{|c|}{ Volatility Measure } \\
\hline & MAC & RMSC & SDL \\
\hline Independent variables & & & $3.70^{* *}$ \\
\hline Constant & $1.00^{* *}$ & $1.36^{* *}$ & $(4.97)$ \\
\hline Episode length & $(7.96)$ & $(7.33)$ & $0.167^{* *}$ \\
(quarters) & 0.0013 & 0.0065 & $(5.56)$ \\
\hline In (per capita GDP) & $(0.25)$ & $(0.87)$ & $-0.505^{* *}$ \\
& $-0.130^{* *}$ & $-0.188^{* *}$ & $(-4.12)$ \\
\hline Openness & $(-6.24)$ & $(-6.15)$ & -0.773 \\
& $-0.296^{*}$ & -0.340 & $(-1.07)$ \\
\hline TOT volatility & $(-2.42)$ & $(-1.89)$ & $0.0623^{* *}$ \\
& $0.0178^{* *}$ & $0.0179^{* *}$ & $(3.25)$ \\
\hline Monthly inflation rate & $(5.49)$ & $(3.74)$ & $1.95^{* *}$ \\
& $0.446^{* *}$ & $0.495^{* *}$ & $(6.24)$ \\
\hline Regime dummies & $(8.44)$ & $(6.34)$ & $-1.32^{*}$ \\
\hline Hard peg (1 or 2) & & & $(-2.27)$ \\
\hline Basket peg & -0.078 & -0.176 & -1.22 \\
(subset of 3) & $(-0.78)$ & $(-1.21)$ & $(-1.61)$ \\
\hline Conventional band (4) & -0.046 & 0.188 & 0.244 \\
& $(-0.36)$ & $(0.99)$ & $(0.39)$ \\
\hline Crawl (5 or 6) & 0.040 & 0.124 & -1.02 \\
& $(0.38)$ & $(0.80)$ & $(-1.69)$ \\
\hline Managed float (7) & $-0.218^{*}$ & -0.147 & 0.704 \\
& $(-2.12)$ & $(-0.97)$ & $(1.28)$ \\
\hline Independent float (8) & $0.252^{* *}$ & $0.362^{* *}$ & $\left(4.37^{* *}\right.$ \\
\hline With zero weight & $(2.71)$ & $(2.64)$ & 0.835 \\
\hline $0.634^{* *}$ & $0.792^{* *}$ & $(5.60)$ & 274 \\
\hline Mean weight & $(6.60)$ & 18 & 9 \\
\hline
\end{tabular}

Notes. Figures in parentheses are heteroscedasticity-robust $t$-statistics. ${ }^{*}\left({ }^{* *}\right)$ denotes significantly different from zero at the 0.05 (0.01) level. For definition of volatility measures see equation (1). Sample excludes all episodes shorter than four quarters and with monthly inflation $>0.03$. The estimation method is the Stata "rreg" command, which uses weighted least squares, with weights based on the absolute size of the residual, after omitting all observations for which Cook's distance exceeds one. The omitted regime category is a conventional single-currency peg. 
Table 10. Using Logarithmic Volatility Measures

\begin{tabular}{|c|c|c|c|}
\hline & \multicolumn{3}{|c|}{ Volatility Measure } \\
\hline & $\ln (\mathrm{MAC})$ & $\ln (\mathrm{RMSC})$ & $\ln (\mathrm{SDL})$ \\
\hline \multicolumn{4}{|l|}{ Independent variables } \\
\hline Constant & $\begin{array}{l}-4.68 * * \\
(-36.7) \\
\end{array}$ & $\begin{array}{l}-4.39 * * \\
(-29.3)\end{array}$ & $\begin{array}{l}-3.25^{* *} \\
(-20.4) \\
\end{array}$ \\
\hline $\begin{array}{l}\text { Episode length } \\
\text { (quarters) }\end{array}$ & $\begin{array}{l}-0.352 \\
(-0.76)\end{array}$ & $\begin{array}{l}0.283 \\
(0.51)\end{array}$ & $\begin{array}{l}3.48^{* *} \\
(5.26)\end{array}$ \\
\hline ln (per capita GDP) & $\begin{array}{c}-0.099 * * \\
(-5.34)\end{array}$ & $\begin{array}{c}-0.121^{* *} \\
(-5.21) \\
\end{array}$ & $\begin{array}{c}-0.088^{* *} \\
(-3.42) \\
\end{array}$ \\
\hline Openness & $\begin{array}{c}-0.243^{*} \\
(-2.08)\end{array}$ & $\begin{array}{l}-0.270 \\
(-1.79)\end{array}$ & $\begin{array}{l}-0.348^{*} \\
(-2.32)\end{array}$ \\
\hline TOT volatility & $\begin{array}{l}1.67 * * \\
(4.49) \\
\end{array}$ & $\begin{array}{l}1.91^{* *} \\
(4.24)\end{array}$ & $\begin{array}{l}1.63^{* *} \\
(4.14) \\
\end{array}$ \\
\hline Monthly inflation rate & $\begin{array}{l}37.7^{* *} \\
(7.51)\end{array}$ & $\begin{array}{l}43.4^{* *} \\
(7.03)\end{array}$ & $\begin{array}{r}49.9 * * \\
(6.79)\end{array}$ \\
\hline \multicolumn{4}{|l|}{ Regime dummies } \\
\hline Hard peg (1 or 2$)$ & $\begin{array}{l}-0.041 \\
(-0.48) \\
\end{array}$ & $\begin{array}{l}0.006 \\
(0.05) \\
\end{array}$ & $\begin{array}{l}-0.099 \\
(-0.76) \\
\end{array}$ \\
\hline $\begin{array}{c}\text { Basket peg } \\
\text { (subset of 3) }\end{array}$ & $\begin{array}{l}-0.045 \\
(-0.37) \\
\end{array}$ & $\begin{array}{l}0.046 \\
(0.27) \\
\end{array}$ & $\begin{array}{l}-0.214 \\
(-1.12) \\
\end{array}$ \\
\hline Conventional band (4) & $\begin{array}{l}-0.018 \\
(-0.20)\end{array}$ & $\begin{array}{l}0.063 \\
(0.63)\end{array}$ & $\begin{array}{l}-0.092 \\
(-1.12)\end{array}$ \\
\hline Crawl (5 or 6 ) & $\begin{array}{l}-0.167 \\
(-1.63)\end{array}$ & $\begin{array}{l}-0.192 \\
(-1.71)\end{array}$ & $\begin{array}{l}-0.346 * \\
(-2.57)\end{array}$ \\
\hline Managed float (7) & $\begin{array}{l}0.162 \\
(1.84)\end{array}$ & $\begin{array}{l}0.174 \\
(1.69)\end{array}$ & $\begin{array}{l}0.036 \\
(0.31)\end{array}$ \\
\hline Independent float (8) & $\begin{array}{c}0.564^{* *} \\
(6.30) \\
\end{array}$ & $\begin{array}{c}0.561 * * \\
(5.41) \\
\end{array}$ & $\begin{array}{c}0.389 * * \\
(3.14) \\
\end{array}$ \\
\hline Observations & 274 & 274 & 274 \\
\hline R-squared & 0.640 & 0.568 & 0.465 \\
\hline Standard error & 0.359 & 0.457 & 0.526 \\
\hline
\end{tabular}

Notes. Figures in parentheses are heteroscedasticity-robust $t$-statistics. $*(* *)$ denotes significantly different from zero at the 0.05 (0.01) level. For definition of volatility measures see equation (1). Sample excludes all episodes shorter than four quarters and with monthly inflation $>0.03$. The omitted regime category is a conventional single-currency peg. 
To address this issue we take logarithms of the volatility measures. As well as reducing skewness, this greatly reduces the outlier problem, and makes the robust regression results (not shown for this case) much more similar to the OLS results. It also has the advantage that the coefficients of the regime dummies now represent estimated proportional effects, which makes them comparable across volatility measures. The results with logarithmic volatility measures appear in Table 10. The regressions are pretty similar across measures, with per capita GDP, terms-of-trade volatility and inflation much the most significant variables. Openness is significant only at the 0.05 level, and as before episode length matters only for the levels measure $(S D L)$. Relative to a conventional single-currency peg (the omitted category), independent floats are estimated to increase volatility by about $75\left(=\mathrm{e}^{0.56}\right) \%$, using either MAC or RMSC, and crawls to reduce it by an insignificant $15-20 \%$. Using $S D L$, the independent float effect is estimated as $+48\left(=\mathrm{e}^{0.39}\right) \%$, and the crawl effect at a significant $-29\left(=\mathrm{e}^{-0.35}\right) \%$. All of the regime dummies are less positive (or more negative) using $S D L$, which indicates that volatility is estimated to be higher in the omitted category of conventional pegs (relative to other categories) using this measure.

As mentioned earlier, the inflation effect on real exchange rate volatility may be stronger under a peg (other than a crawl, which is explicitly designed to adjust for relative inflation rates). To test this, we now allow the inflation effect to be different for regime categories 1 to 4 (horizontal pegs and bands) relative to categories 5 to 8 (crawls and floats), by including an additional variable that is equal to the inflation rate for regimes 1 
to 4 , and equal to zero for regimes 5 to 8 . The results are shown in Table 11 . The new variable is always significantly positive at the 0.05 level, and with a coefficient similar to that of the inflation rate, which implies that the inflation effect is approximately twice as strong under a peg. This is consistent with the hypothesis that there are political costs to adjusting a peg.

The coefficients of the regime dummies have a different interpretation in Table 11 from in previous tables. For crawling pegs and bands and for floats, they now indicate only the estimated effect relative to a single-currency peg at a zero inflation rate. To calculate the regime effect at any positive inflation rate, the impact of the coefficient of the inflation rate times the dummy for regime 1 to 4 must also be taken into account. Crawling pegs and bands are now estimated to have no effect on volatility relative to a single-currency peg at zero inflation, which makes sense, while independent floats add $71\left(=\mathrm{e}^{0.54}\right)$ to 112 $\left(=\mathrm{e}^{0.75}\right) \%$ to volatility at zero inflation, and managed floats add 25 to $51 \%$, depending on which volatility measure is used. At a monthly inflation rate of 0.01 , however, crawling pegs and bands would reduce inflation significantly; managed floats would make little difference; and independent floats would increase volatility but by substantially less than at zero inflation. ${ }^{9}$

\footnotetext{
${ }^{9}$ This can be seen by subtracting 0.01 times the coefficient of (inflation times regime 1 to 4 dummy) from the coefficient of the dummy for the relevant exchange rate regime.
} 
Table 11. Allowing for Regime-Specific Inflation Effects

\begin{tabular}{|c|c|c|c|}
\hline & \multicolumn{3}{|c|}{ Volatility Measure } \\
\hline & $\ln (\mathrm{MAC})$ & $\ln ($ RMSC) & $\ln (\mathrm{SDL})$ \\
\hline \multicolumn{4}{|l|}{ Independent variables } \\
\hline Constant & $\begin{array}{l}-4.80 * * \\
(-38.7)\end{array}$ & $\begin{array}{l}-4.56^{* *} \\
(-30.4)\end{array}$ & $\begin{array}{l}-3.38^{* *} \\
(-21.2)\end{array}$ \\
\hline $\begin{array}{c}\text { Episode length } \\
\text { (quarters) }\end{array}$ & $\begin{array}{l}-0.264 \\
(-0.57)\end{array}$ & $\begin{array}{l}0.407 \\
(0.74)\end{array}$ & $\begin{array}{c}3.58^{* *} \\
(5.44)\end{array}$ \\
\hline $\ln$ (per capita GDP) & $\begin{array}{c}-0.098^{* *} \\
(-5.38)\end{array}$ & $\begin{array}{c}-0.120^{* *} \\
(-5.28)\end{array}$ & $\begin{array}{c}-0.088^{* *} \\
(-3.41)\end{array}$ \\
\hline Openness & $\begin{array}{l}-0.213 \\
(-1.89)\end{array}$ & $\begin{array}{l}-0.228 \\
(-1.57)\end{array}$ & $\begin{array}{l}-0.315^{*} \\
(-2.16)\end{array}$ \\
\hline TOT volatility & $\begin{array}{l}1.66 * * \\
(4.61)\end{array}$ & $\begin{array}{l}1.91^{* *} \\
(4.40)\end{array}$ & $\begin{array}{l}1.63^{* *} \\
(4.14)\end{array}$ \\
\hline Monthly inflation rate & $\begin{array}{l}30.4^{* *} \\
(5.51)\end{array}$ & $\begin{array}{l}33.3^{* *} \\
(5.01)\end{array}$ & $\begin{array}{l}41.9 * * \\
(5.40)\end{array}$ \\
\hline $\begin{array}{l}\text { Inflation times } \\
\text { regimes } 1 \text { to } 4 \text { dummy }\end{array}$ & $\begin{array}{l}28.7^{* *} \\
(2.81)\end{array}$ & $\begin{array}{l}40.1^{* *} \\
(3.03)\end{array}$ & $\begin{array}{l}31.7^{*} \\
(2.03)\end{array}$ \\
\hline \multicolumn{4}{|l|}{ Regime dummies } \\
\hline Hard peg (1 or 2$)$ & $\begin{array}{l}-0.015 \\
(-0.18)\end{array}$ & $\begin{array}{l}0.043 \\
(0.39) \\
\end{array}$ & $\begin{array}{l}-0.069 \\
(-0.53) \\
\end{array}$ \\
\hline $\begin{array}{c}\text { Basket peg } \\
\text { (subset of 3) }\end{array}$ & $\begin{array}{l}-0.103 \\
(-0.89)\end{array}$ & $\begin{array}{l}-0.035 \\
(-0.21)\end{array}$ & $\begin{array}{l}-0.278 \\
(-1.51)\end{array}$ \\
\hline Conventional band (4) & $\begin{array}{l}0.000 \\
(0.00)\end{array}$ & $\begin{array}{l}0.089 \\
(0.91)\end{array}$ & $\begin{array}{l}-0.071 \\
(-0.54)\end{array}$ \\
\hline Crawl (5 or 6 ) & $\begin{array}{l}0.100 \\
(0.09)\end{array}$ & $\begin{array}{l}0.055 \\
(0.42)\end{array}$ & $\begin{array}{l}-0.151 \\
(-1.00)\end{array}$ \\
\hline Managed float (7) & $\begin{array}{c}0.331^{* *} \\
(3.48)\end{array}$ & $\begin{array}{c}0.410^{* *} \\
(3.43) \\
\end{array}$ & $\begin{array}{l}0.222 \\
(1.60) \\
\end{array}$ \\
\hline Independent float (8) & $\begin{array}{c}0.700^{* *} \\
(7.67)\end{array}$ & $\begin{array}{c}0.752^{* *} \\
(6.84)\end{array}$ & $\begin{array}{c}0.539 * * \\
(4.07)\end{array}$ \\
\hline Observations & 274 & 274 & 274 \\
\hline R-squared & 0.653 & 0.541 & 0.477 \\
\hline Standard error & 0.353 & 0.471 & 0.521 \\
\hline Chow stat. $\mathrm{F}(9,256)$ & 0.63 & 0.49 & 0.46 \\
\hline
\end{tabular}

Notes. Figures in parentheses are heteroscedasticity-robust $t$-statistics. ${ }^{*}(* *)$ denotes significantly different from zero at the $0.05(0.01)$ level. For definition of volatility measures see equation (1). Sample excludes all episodes shorter than four quarters and with monthly inflation $>0.03$. The omitted regime category is a conventional single-currency peg. The Chow statistic refers to the hypothesis that the coefficients are identical between advanced and developing countries, and for enhanced power is based on a regression with only two regime dummies (managed and independent float). The 0.05 critical value is 1.89. 
This sheds a new light on the phenomenon of "fear of floating", or the tendency for floats to be managed in the developing world (Calvo and Reinhart, 2002). This has been widely interpreted, as the phrase implies, to mean that countries are intellectually convinced of the merits of an independent float but unwilling in practice to accept the resulting real exchange rate volatility. The results obtained here suggest an alternative interpretation: managed floats are adopted not out of any intellectual enthusiasm for floating but for the pragmatic reason that they are a more effective way of controlling real exchange rate volatility in the presence of significant inflation, given the reluctance to adjust the parity under a peg. This is consistent with the statistical association of managed floats with relatively high inflation rates, as shown in Table 4.

The Chow statistics at the foot of Table 11 show that there is no significant difference in coefficients between developing countries (199 observations) and advanced countries (75 observations). It is interesting, therefore, to use these regressions to examine the contribution of each variable to the model's "explanation" of the much higher average volatility in developing countries. Table 12 shows that the observed average difference is rather smaller (although still substantial) using the standard deviation of the real exchange rate level rather than changes. About half of this average difference is explained by factors other than per capita GDP (which might be interpreted as the element the model has failed to explain), mainly inflation and terms-of-trade volatility. Developing countries' choice of exchange rate regime (principally a much lower frequency of independent floats) has helped to reduce volatility. 
Table 12. Explaining Higher Volatility in Developing Countries

\begin{tabular}{|c|c|c|c|}
\hline $\begin{array}{c}\text { Average difference between } \\
\text { developing and advanced } \\
\text { countries }\end{array}$ & \multicolumn{3}{|c|}{ Volatility Measure } \\
\hline & ln (MAC) & $\ln$ (RMSC) & $\ln$ (SDL) \\
\hline Observed & +0.51 & +0.59 & +0.38 \\
\hline Explained by: & & & -0.07 \\
\hline Episode length & -0.01 & -0.01 & +0.22 \\
\hline Per capita GDP & +0.25 & +0.31 & -0.01 \\
\hline Openness & -0.01 & -0.01 & +0.18 \\
\hline TOT volatility & +0.14 & +0.16 & +0.21 \\
\hline Inflation & +0.16 & +0.17 & +0.03 \\
\hline Inflation x peg dummy & +0.03 & +0.04 & +0.05 \\
\hline Managed float dummy & +0.07 & +0.08 & -0.13 \\
\hline Independent float dummy & -0.17 & -0.18 & \\
\hline
\end{tabular}

Notes. The Table shows the difference in mean values of each variable between developing and advanced countries, multiplied by the coefficients of the relevant regression in Table 11.

\subsection{Further hypotheses}

In this section we consider three further hypotheses. The first is that capital controls reduce volatility by inhibiting speculative capital flows (as is intended in Chile, for example). To test this we introduce a dummy for the existence of controls on capital transactions, as reported in the IMF Annual Report on Exchange Arrangements and Exchange Restrictions. Secondly we test whether inflation targeting reduces real effective exchange rate volatility relative to what would be expected, given that it tends to be associated with floating rates, as is suggested by the results of Rose (2007) for a more limited sample. For this we use a dummy for an inflation targeting regime, based on the data in Rose (2007, Table A1). Finally we test whether financial development, as measured by the log of one plus the ratio of M3 to GDP, reduces volatility, as found by 
Devereux and Lane (2003). Table 13 shows the effects of adding these two variables to the regressions shown in Table 11.

In Table 13, the four insignificant regime dummies (hard peg, basket peg, conventional band and crawling peg and band) have been omitted. Since they tended to have negative coefficients, their omission makes the dummies for managed and independent floats more positive and more significant.

Capital controls have a consistently positive coefficient, contrary to the view that they reduce volatility, although it is never statistically significant. The most likely explanation for this is reverse causality - that countries with naturally greater real exchange rate volatility are more tempted to impose capital controls in an attempt to reduce it. The fact that the estimated coefficient is positive shows that any effect of controls in reducing volatility is either negligible or too small to outweigh this selection effect.

The inflation targeting dummy is also insignificant in all three cases, and (perhaps surprisingly) positive. The difference between this result and that of Rose (2007) is probably explained by the fact that we control for the inflation effect. Since inflation targeting reduces inflation, it will tend to reduce real exchange rate volatility through this mechanism.

Although the financial development variable always has a negative coefficient, as expected, it also is never statistically significant. 
$\underline{\text { Table 13. Capital Controls, Inflation Targeting and Financial Development }}$

\begin{tabular}{|c|c|c|c|}
\hline & \multicolumn{3}{|c|}{ Volatility Measure } \\
\hline & $\ln (\mathrm{MAC})$ & $\ln (\mathrm{RMSC})$ & $\ln (\mathrm{SDL})$ \\
\hline \multicolumn{4}{|l|}{ Independent variables } \\
\hline Constant & $\begin{array}{l}-4.79 * * \\
(-48.7)\end{array}$ & $\begin{array}{l}-4.46 * * \\
(-34.6)\end{array}$ & $\begin{array}{l}-3.44^{* *} \\
(-25.5)\end{array}$ \\
\hline $\begin{array}{l}\text { Episode length } \\
\text { (quarters) }\end{array}$ & $\begin{array}{l}-0.427 \\
(-1.01)\end{array}$ & $\begin{array}{l}0.336 \\
(0.68)\end{array}$ & $\begin{array}{l}3.34 * * \\
(5.47)\end{array}$ \\
\hline $\ln$ (per capita GDP) & $\begin{array}{c}-0.0842^{* *} \\
(-3.95)\end{array}$ & $\begin{array}{c}-0.0926^{* *} \\
(-3.51)\end{array}$ & $\begin{array}{c}-0.0779 * \\
(-2.50)\end{array}$ \\
\hline Openness & $\begin{array}{l}-0.215 \\
(-1.92)\end{array}$ & $\begin{array}{l}-0.241 \\
(-1.69)\end{array}$ & $\begin{array}{l}-0.281 \\
(-1.91)\end{array}$ \\
\hline TOT volatility & $\begin{array}{l}1.57 * * \\
(4.50)\end{array}$ & $\begin{array}{l}1.63 * * \\
(3.91)\end{array}$ & $\begin{array}{l}1.64 * * \\
(4.03)\end{array}$ \\
\hline Monthly inflation rate & $\begin{array}{l}29.6^{* *} \\
(6.41)\end{array}$ & $\begin{array}{l}31.0^{* *} \\
(5.40)\end{array}$ & $\begin{array}{l}38.6 * * \\
(5.22)\end{array}$ \\
\hline $\begin{array}{l}\text { Inflation times } \\
\text { regimes } 1 \text { to } 4 \text { dummy }\end{array}$ & $\begin{array}{l}25.7^{* *} \\
(2.98)\end{array}$ & $\begin{array}{l}38.1^{* *} \\
(3.36)\end{array}$ & $\begin{array}{l}33.7^{*} \\
(2.50)\end{array}$ \\
\hline \multicolumn{4}{|l|}{ Regime dummies } \\
\hline Managed float (7) & $\begin{array}{c}0.344^{* *} \\
(5.35) \\
\end{array}$ & $\begin{array}{c}0.393^{* *} \\
(4.99) \\
\end{array}$ & $\begin{array}{c}0.338 * * \\
(3.60) \\
\end{array}$ \\
\hline Independent float (8) & $\begin{array}{c}0.710^{* *} \\
(11.2)\end{array}$ & $\begin{array}{c}0.743 * * \\
(9.42)\end{array}$ & $\begin{array}{c}0.622 * * \\
(6.82)\end{array}$ \\
\hline \multicolumn{4}{|l|}{ Extra variables } \\
\hline $\begin{array}{c}\text { Capital controls } \\
\text { dummy }\end{array}$ & $\begin{array}{l}0.066 \\
(1.22) \\
\end{array}$ & $\begin{array}{l}0.103 \\
(1.54)\end{array}$ & $\begin{array}{l}0.009 \\
(0.11)\end{array}$ \\
\hline $\begin{array}{c}\text { Inflation targeting } \\
\text { dummy }\end{array}$ & $\begin{array}{l}0.058 \\
(0.92)\end{array}$ & $\begin{array}{l}0.008 \\
(0.12)\end{array}$ & $\begin{array}{l}0.100 \\
(1.08)\end{array}$ \\
\hline $\begin{array}{c}\text { Financial development } \\
{[\ln (1+\mathrm{M} 3 / \mathrm{GDP})]}\end{array}$ & $\begin{array}{l}-0.125 \\
(-0.83)\end{array}$ & $\begin{array}{l}-0.250 \\
(-1.34)\end{array}$ & $\begin{array}{l}-0.155 \\
(-0.69)\end{array}$ \\
\hline Observations & 271 & 271 & 271 \\
\hline R-squared & 0.657 & 0.596 & 0.476 \\
\hline Standard error & 0.352 & 0.444 & 0.522 \\
\hline
\end{tabular}

Notes. Figures in parentheses are heteroscedasticity-robust $t$-statistics. ${ }^{*}(* *)$ denotes significantly different from zero at the 0.05 (0.01) level. For definition of volatility measures see equation (1). Sample excludes all episodes shorter than four quarters and with monthly inflation $>0.03$. The omitted regime category is a conventional single-currency peg. 


\subsection{Sample selection bias}

There is a possibility that the results are subject to sample selection bias, because real effective exchange rate indices are not available for many countries. To test for this, we have constructed measures of the standard deviation of the level of the real bilateral exchange rate against the US dollar, using consumer price indices. This expands the sample to 154 countries and 493 episodes. We estimate a regression for the log of bilateral real exchange rate volatility that is identical in structure to that in Table 11 , except that we also include a dummy for attachment to a currency that has floated against the US dollar (this dummy is equal to one for all countries in Europe and North Africa that are on a peg, and for countries pegged to the South African rand). We then reestimate this regression for countries with and without real effective exchange rate data, and calculate the Chow statistic. The results are shown in Table 14. Since the Chow statistic is not significant at the 0.05 level, we conclude that sample selection bias is not a major problem. ${ }^{10}$

\footnotetext{
${ }^{10}$ The coefficients are a bit different in some cases for real bilateral rates, but that is an issue for another paper.
} 
Table 14. Testing for Sample Selection Bias

\begin{tabular}{|c|c|c|c|}
\hline & \multicolumn{3}{|c|}{$\begin{array}{c}\text { Dependent variable: In (standard deviation of the US\$ } \\
\text { bilateral real exchange rate) }\end{array}$} \\
\hline & Full sample & $\begin{array}{l}\text { With REER } \\
\text { data }\end{array}$ & $\begin{array}{l}\text { Without REER } \\
\text { data }\end{array}$ \\
\hline \multicolumn{4}{|l|}{ Independent variables } \\
\hline Constant & $\begin{array}{c}-3.32 * * \\
(-21.1)\end{array}$ & $\begin{array}{c}-3.23 * * \\
(-14.6)\end{array}$ & $\begin{array}{r}-3.49 * * \\
(-13.7)\end{array}$ \\
\hline $\begin{array}{l}\text { Episode length } \\
\text { (quarters) }\end{array}$ & $\begin{array}{r}4.10^{* *} \\
(7.58)\end{array}$ & $\begin{array}{l}3.83^{* *} \\
(4.84)\end{array}$ & $\begin{array}{c}4.57^{* *} \\
(5.80)\end{array}$ \\
\hline $\ln$ (per capita GDP) & $\begin{array}{c}-0.104^{* *} \\
(-4.53)\end{array}$ & $\begin{array}{c}-0.089 * * \\
(-2.72)\end{array}$ & $\begin{array}{c}-0.149 * * \\
(-3.71)\end{array}$ \\
\hline Openness & $\begin{array}{c}-0.478^{* *} \\
(-3.13)\end{array}$ & $\begin{array}{c}-0.653^{* *} \\
(-3.21)\end{array}$ & $\begin{array}{l}-0.149 \\
(-0.70)\end{array}$ \\
\hline TOT volatility & $\begin{array}{l}0.177 \\
(0.36)\end{array}$ & $\begin{array}{l}0.135 \\
(0.23)\end{array}$ & $\begin{array}{l}0.335 \\
(0.43)\end{array}$ \\
\hline Monthly inflation rate & $\begin{array}{r}39.0 * * \\
(5.64)\end{array}$ & $\begin{array}{l}33.6^{* *} \\
(3.22)\end{array}$ & $\begin{array}{l}50.2^{* *} \\
(4.84)\end{array}$ \\
\hline $\begin{array}{l}\text { Inflation times } \\
\text { regimes } 1 \text { to } 4 \text { dummy }\end{array}$ & $\begin{array}{c}19.2 \\
(1.63)\end{array}$ & $\begin{array}{l}36.4^{*} \\
(2.23)\end{array}$ & $\begin{array}{l}-3.23 \\
(-0.19)\end{array}$ \\
\hline $\begin{array}{c}\text { Dummy for non-US\$ } \\
\text { attachment }\end{array}$ & $\begin{array}{c}0.668^{* *} \\
(8.01)\end{array}$ & $\begin{array}{c}0.642 * * \\
(5.95)\end{array}$ & $\begin{array}{c}0.720 * * \\
(4.61)\end{array}$ \\
\hline \multicolumn{4}{|l|}{ Regime dummies } \\
\hline Hard peg (1 or 2$)$ & $\begin{array}{c}0.561 * * \\
(4.67)\end{array}$ & $\begin{array}{l}0.464 * \\
(2.54)\end{array}$ & $\begin{array}{c}0.641 * * \\
(3.95)\end{array}$ \\
\hline $\begin{array}{c}\text { Basket peg } \\
\text { (subset of 3) }\end{array}$ & $\begin{array}{c}0.392 * * \\
(2.95)\end{array}$ & $\begin{array}{l}0.302 \\
(1.58)\end{array}$ & $\begin{array}{l}0.457^{*} \\
(2.51)\end{array}$ \\
\hline Conventional band (4) & $\begin{array}{c}0.428^{* *} \\
(3.75)\end{array}$ & $\begin{array}{c}0.400 * * \\
(2.63)\end{array}$ & $\begin{array}{c}0.537 * * \\
(2.74)\end{array}$ \\
\hline Crawl (5 or 6 ) & $\begin{array}{l}0.069 \\
(0.45)\end{array}$ & $\begin{array}{l}0.085 \\
(0.42)\end{array}$ & $\begin{array}{l}0.089 \\
(0.34)\end{array}$ \\
\hline Managed float (7) & $\begin{array}{c}0.554 * * \\
(4.56)\end{array}$ & $\begin{array}{c}0.697 * * \\
(3.89)\end{array}$ & $\begin{array}{l}0.367^{*} \\
(2.13)\end{array}$ \\
\hline Independent float (8) & $\begin{array}{c}0.740 * * \\
(6.00)\end{array}$ & $\begin{array}{c}0.832 * * \\
(5.19)\end{array}$ & $\begin{array}{l}0.511^{*} \\
(2.44)\end{array}$ \\
\hline Observations & 493 & 267 & 221 \\
\hline R-squared & 0.378 & 0.390 & 0.399 \\
\hline Standard error & 0.658 & 0.648 & 0.672 \\
\hline Chow stat. $F(14,465)$ & & & \\
\hline
\end{tabular}

Notes. Figures in parentheses are heteroscedasticity-robust $t$-statistics. ${ }^{*}(* *)$ denotes significantly different from zero at the $0.05(0.01)$ level. Sample excludes all episodes shorter than four quarters and with monthly inflation $>0.03$. The omitted regime category is a conventional single-currency peg. The 0.05 critical value of the Chow statistic is 1.70 . 


\section{Conclusions}

This paper has presented a new analysis of real effective exchange rate volatility, using a sample of 90 countries. After controlling for other factors, volatility is higher in poorer countries and those with more terms-of-trade volatility. Volatility increases markedly with the inflation rate, even at moderate levels (observations with inflation above three per cent per month were excluded throughout). The inflation effect is stronger in pegged regimes, which is consistent with the view that adjusting a peg is costly. Inflationary problems and greater terms-of-trade volatility explain about half of the $40-60 \%$ higher volatility in developing countries in this sample. Geographical factors, as reflected in the ratio of international trade to GDP, are marginally significant but of minor importance relative to inflation, terms-of-trade volatility and per capita GDP.

The choice of exchange rate regime can make a substantial difference to real effective exchange rate volatility over and above these effects. At average inflation rates, an independent float adds about $48 \%$ to volatility (measured as the standard deviation of the level), or alternatively about $75 \%$ (using measures based on monthly changes) relative to a conventional peg. A crawling peg or band tends to reduce volatility by about $20 \%$ (but to a statistically significant degree only for one out of three measures). Crawls seem to represent the closest approximation to a regime of real exchange rate targeting. Real exchange rate volatility under other regimes is not significantly different from under a conventional peg: for instance there is no evidence that basket pegs deliver significantly lower real effective exchange rate volatility than single-currency pegs, even though they 
might be expected to do so, since the basket is usually a better reflection of a country's trade pattern.

Under less flexible regimes, real effective exchange rate volatility is significantly more sensitive to inflation than under more flexible regimes. This probably reflects a reluctance to adjust the parity to offset inflation differentials, either through inertia or because of perceived political costs. Managed floats are better than conventional pegs at delivering lower real exchange rate volatility at higher inflation rates, and it is noticeable that managed floats are more frequently observed in higher-inflation situations. This suggests that managed floats are adopted more out of pragmatic considerations than out of an intellectual conviction of the merits of floating. They probably represent a "reluctance to peg" in inflationary situations more than a "fear of floating".

We found no evidence that capital controls or inflation targeting reduce exchange rate volatility. Finally, although real effective exchange rate data are absent for many countries, estimation of a similar equation using bilateral real exchange rate volatility against the US dollar does not suggest any problem of sample selection bias.

\section{REFERENCES}

Aghion, P., Bacchetta, P., Rancière, R. and Rogoff, K. (2006) Exchange rate volatility and productivity growth: the role of financial development, NBER Working Paper no. 12117

Barisone, G., Driver, R.L. and Wren-Lewis, S. (2006) Are our FEERs justified? Journal of International Money and Finance 25, 741-759 
Baxter, M. and Stockman, A.C. (1989) Business cycles and the exchange-rate regime: some international evidence, Journal of Monetary Economics 23, 377-430

Bergin, P.R. (2006) How well can the New Open Economy Macroeconomics explain the exchange rate and the current account? Journal of International Money and Finance 25, 675-701

Bleaney, M.F. (1996) Macroeconomic stability, investment and growth in developing countries, Journal of Development Economics 48, 461-477

Bleaney, M.F. (2008) Openness and real exchange rate volatility: in search of an explanation, Open Economies Review 19, 135-146

Bleaney, M.F. and Francisco, M. (2007) Classifying exchange rate regimes: a statistical analysis of alternative methods, Economics Bulletin 6 (3), 1-6

Bleaney, M.F. and Francisco, M. (2008) Balance sheet effects and the choice of exchange rate regime in developing countries, Journal of International Trade and Economic Development 17, 297-310

Bravo-Ortega, C. and di Giovanni, J. (2006) Remoteness and real exchange rate volatility, IMF Staff Papers 53 (Special Issue), 115-132

Bubula, A. and Ötker-Robe, I. (2002) The evolution of exchange rate regimes since 1990: evidence from de facto policies, IMF Working Paper no. 02/155

Calvo, G. and Reinhart, C.M. (2002) Fear of floating, Quarterly Journal of Economics 117, 379-408

Clark, P., Tamirisa, N. and Wei, S.-J. (2004) A new look at exchange rate volatility and trade flows, IMF Occasional Paper no. 235

Devereux, M.B. and Lane, P. (2003) Understanding bilateral exchange rate volatility, Journal of International Economics 60, 109-132

Flood, R.P. and Rose, A.K. (1995) Fixing exchange rates: a virtual quest for fundamentals, Journal of Monetary Economics 36, 3-37

Frankel, J.A. (2005) Contractionary currency crashes in developing countries, IMF Staff Papers 52(2), 149-91

Gonzaga, G.M. and Terra, M.C.T. (1997) Equilibrium real exchange rate, volatility, and stabilization, Journal of Development Economics 54, 77-100 
Hasan, S. and Wallace, M. (1996) Real exchange rate volatility and exchange rate regimes: evidence from long-term data, Economics Letters 52, 67-73

Hau, H. (2002) Real exchange rate volatility and openness: theory and evidence, Journal of Money Credit and Banking 34, 611-630

Hausmann, R., Panizza, U. and Rigobon, R. (2006) The long-run volatility puzzle of the real exchange rate, Journal of International Money and Finance 25, 93-124

Hausmann, R., Panizza, U. and Stein, E. (2001) Why do countries float the way they float? Journal of Development Economics 66, 387-414

Lane, P.R. and Shambaugh, J.C. (2007) Financial exchange rates and international currency exposures, NBER Working Paper no. 13433

Levy-Yeyati, Eduardo, and Federico Sturzenegger (2005) Classifying exchange rate regimes: deeds versus words, European Economic Review 49, 1603-35

Mussa, M. (1986) Nominal exchange rate regimes and the behavior of real exchange rates: evidence and implications, Carnegie-Rochester Conference Series on Public Policy 25, 117-214

Obstfeld, M. and Rogoff, K. (2000) The six major puzzles in international macroeconomics: is there a common cause? In Bernanke, B. and Rogoff, K. (eds), NBER Macroeconomics Annual, 15, 339-390

Reinhart, C.M. and Rogoff, K. (2004) The modern history of exchange rate arrangements: a reinterpretation, Quarterly Journal of Economics 119, 1-48

Reitz, S. and Taylor, M.P. (2008) The coordination channel of foreign exchange intervention: a nonlinear microstructural analysis, European Economic Review 52, 5576

Rose, A.K. (1996) Explaining exchange rate volatility: an empirical analysis of 'the holy trinity' of monetary independence, fixed exchange rates, and capital mobility, Journal of International Money and Finance 6, 925-945

Rose, A.K. (2007) A stable international monetary system emerges: inflation targeting is Bretton Woods, reversed, Journal of International Money and Finance 26, 663-681

Shambaugh, J. (2004) The effect of fixed exchange rates on monetary policy, Quarterly Journal of Economics 119, 301-52 
Williamson, J. and Mahar, M. (1998) Current account targets, in S. Wren-Lewis and R.L. Driver (eds), Real Exchange Rates for the Year 2000 (Washington DC: Institute for International Economics)

\section{APPENDIX}

\section{Countries in the sample}

Industrial countries (23)

Australia, Austria, Belgium, Canada, Denmark, Finland, France, Germany, Greece, Iceland, Ireland, Italy, Japan, Luxembourg, Netherlands, New Zealand, Norway, Portugal, Spain, Sweden, Switzerland, United Kingdom, United States

Developing Countries (67)

Algeria, Antigua and Barbuda, Armenia, Bahamas, Bahrain, Belize, Bolivia, Bulgaria, Burundi, Cameroon, Central African Republic, Chile, China, Colombia, Costa Rica, Côte d'Ivoire, Croatia, Cyprus, Czech Republic, Democratic Republic of Congo, Dominica, Dominican Republic, Ecuador, Equatorial Guinea, Fiji, Gabon, Gambia, Ghana, Grenada, Guyana, Hungary, Iran, Israel, Lesotho, Malawi, Malaysia, Malta, Moldova, Morocco, Netherlands Antilles, Nicaragua, Nigeria, Pakistan, Papua New Guinea, Paraguay, Philippines, Poland, Romania, Russia, St Kitts and Nevis, St Lucia, St Vincent and the Grenadines, Samoa, Saudi Arabia, Sierra Leone, Singapore, Slovak Republic, Solomon Islands, South Africa, Togo, Trinidad and Tobago, Tunisia, Uganda, Ukraine, Uruguay, Venezuela, Zambia. 